\title{
The Need for Competitive Educational Management PhD Programs in Saudi Arabia
}

\author{
Seham M. S. Kaki \\ Educational Management and Planning, Education College, Princess Nourah bint Abdulrahman University, \\ Riyadh, Saudi Arabia
}

\begin{abstract}
This study assessed the realities of the Saudi labor market and the need for competitive PhD programs in educational management, the aim being to propose a vision for such a program. An analysis of the current educational reality was obtained through interviews, as well as the following information: employer, years of experience, and method of recruitment, along with a number of statements presented to participants for their reaction that were designed to elicit their opinion on the importance of having competitive $\mathrm{PhD}$ programs in leadership. The population for this study consisted of a random sample of stakeholders $(\mathrm{n}=$ 24) in the labor market. Three main results emerged from the study: a) the educational labor market needs to acquire knowledge about a competitive leadership degree at the $\mathrm{PhD}$ level in educational administration. b) A good program for leadership in educational management would provide universities a competitive advantage at the doctoral level. The educational labor market needs academic and professional knowledge from people with doctoral degrees in educational management.
\end{abstract}

Keywords: Competitive, Educational, Management, Saudi labor market, Leadership, Market needs.

Universities have multiple responsibilities and tasks in preparing learning in specialized competencies to bear the burdens of development in various areas of life, in finding scientific solutions to societal problems, and in spreading and developing knowledge in the various branches of science. Universities, therefore, are key for society's progress and/or renewal. The heavy burden of discharging these responsibilities lies with academics and administrators the various departments of the university (Abou al-Wafa, 1990).

Academic Departments are at the heart of the body that is the modern university. Though they are the smallest unit of the university organization, they are actually considered the cornerstone of the university. Nonetheless, the university cannot fulfill its mission or achieve its objectives only through its scientific departments. The real key to doing so, according to Bennett (Emmet, 1992) is to raise universities' level of productivity in terms of both quantity and quality. Most university decisions are controlled at the department level, such as designing academic programs, selecting faculty, determining courses, setting admission and graduation criteria, and assessing the relative importance of various activities, such as teaching, scientific research, and community service. This is perhaps why Wolotkiewicz (1986) emphasized that about $80 \%$ of all administrative decisions in the university are made at the academic departmental level. Departmental function is not confined to making decisions, either; academic department responsibilities extend to implementation and follow-up, guidance, and evaluation. The purpose of academic departments is to identify and study ways to contribute to the development of the environment and society, and to contribute to knowledge management processes between the community and faculty. In sum, the academic department is the effective force in determining the features of the university and its production. The actual realization of the university institution takes place only at the department level (Emmet, 1992).

Thus, within the universities of Saudi Arabia, it is academic departments' responsibility to offer graduate programs in light of the needs of societyis. To bridge the gap between education and career options. Delivering a quality education is a competitive priority for most educational institutions, and having high quality programs is an important competitive weapon that educational institutions use to achieve market excellence (Sayed Mostafa, 2000). So the proposed program equips students with the knowledge and skills that qualify them to lead the business and achieve competitive advantage by taking advantage of the 
privatization and knowledge management programs. This is in line with the requirements of some of the strategic to bridge the gap between education and the society's needs. It is designed in the face of challenges and obstacles.

Organizations normally provide material or moral benefits to their beneficiaries, which for universities are manifest as educational services, knowledge opportunities, educational techniques, opportunities for academic progress and growth, and distinctive educational programs (Selmi, 2017). Economic institutions seek to increase the efficiency and effectiveness of their performance in order to have a competitive advantage, in part by continuously meeting customer needs or developing the competitiveness of the organization. Porter defined "competitive advantage" as the value that an institution can provide to a beneficiary - that is, in having the lowest price as well as being distinguished in some way from other products (Ali, 2016). A university's ability to offer a master's degree in quality management for educational administration at a competitive value, for example, serves to distinguish it from other universities.

The human factor, as represented by human resources and competencies, is one of the most important factors in an institution's acquisition of competitive advantage, as well as its success in penetrating global markets (Knight \& Trowel, 2007).

Focusing on this element by developing and stimulating it, and providing a work environment that positively affects employees' morale is one of the most important pillars of competitive leadership. It is humans who are responsible for making and implementing strategic decisions that result in a competitive advantage for the organization. Thus, loss of competencies and poor performance in human resources because of ineffective management methods are major reasons for the failure of strategic plans (Somali, 2003). Thus, this study addressed the need in the Saudi labor market for educational management programs that specifically promote and develop leadership, which will help organizations to achieve a competitive advantage.

\section{A review of the literature}

Several studies have been conducted that relate in one way or another to the subject of this research, some relating to the Middle East and some with an international focus. A number of them dealt with quality concerns in terms of university programs. Metwally (2006) evaluated select private Egyptian universities in light of their objectives and some societal variables. Following the descriptive method and using a questionnaire to solicit data from a sample of administrative and academic leaders, faculty members, and students of both sexes, Metwally found that the objectives of the university were not always being achieved. By way of remedy, the study recommended freedom from administrative bureaucratic constraints, privatizing university education, providing the latest equipment, developing academic and administrative cadres, and identifying adequate controls for the profit side of private universities.

In a study similarly focused on quality but specifically in relation to the ISO 9000 Series international quality management standards, Sencila and Skipariene (2007) were able to identify methods to assist in achieving quality in higher education: these strategies included establishing clearly defined goals, designing a quality management system that would enable continuous quality assurance, identifying labor market needs, and designing objective measures to determine the satisfaction of each customer. This study emphasized the importance of studying the needs of the labor market in designing academic programs to determine what skills and knowledge graduates need to enter the labor force.

With regard to competitiveness on a global level, Al-Ariani (2007) studied the theoretical literature on university education programs and their ability to compete and adapt to the requirements of globalization. Using a descriptive approach, Al-Araini detailed a number of results, as follows: Global economic and political changes require the response of graduate programs accordingly, which requires development. Such programs must be continuously supported by necessary technologies to meet the challenges of globalization. They must also respond to the changing demands of the labor market, which necessitates the achievement of educational program outputs that require specific skills, knowledge, and experience.

Several studies explored for this research looked at existing conditions in various universities in the Middle East, three of them being in Saudi Arabia. Gaber, Salah Abdel (1992) used a questionnaire in an attempt to determine the obstacles to the application of total quality at King Faisal University. Their results included 
the failure of senior management to adopt the concept of total quality management, lack of material allocations, and weak relationships between departments. They also found a lack of clear standards of measurement, limited effectiveness in training programs, no philosophy of continuous improvement, limited international communication, and a lack of databases, imperfect coordination with scientific research centers, and the absence of a technical educational environment.

In studying the less demanding scientific disciplines in Saudi institutions of higher education, Bader (2009) applied the systems analysis method and a descriptive approach. Bader found that Saudi universities are non-specialized, including theoretical and practical colleges, except for King Fahd University. Some specializations and departments - such as history, geography, and languages in the faculties of Arts and Education, and Arabic are repeated among universities and colleges. Departments of Education occupied the first position in this, and there is also an overlap between the disciplines in the faculties of education and teacher preparation. The study recommended the development of an independent policy by the Supreme Council of Universities to be applied gradually and to promote socio-cultural awareness of the pertinent issues. It also recommended that a feasibility study, in terms of integrating some of the disciplines, be conducted in light of scientific and objective standards linked to the needs of the Saudi labor market.

Two other studies, though specifically applying to female students and their programs in universities, contained valuable concepts that can serve as a springboard for the current exploration of these concepts. In a study from Saudi Arabia, Ayoub (2008) surveyed a random sample from a number of private establishments in Riyadh, as well as some of the female graduates. Ayoub found, first, that female students generally prefer to work in the government sector. Female students looking for work in the private sector were hindered by lack of experience, computer skills, English language knowledge, some of the specializations needed for working in the private sector, and certain personal and behavioral skills. The other study was carried out by examining the lives of working women in both Egypt and Saudi Arabia to compare their professional compatibility with their perceived quality of life in the workplace (Shehata, 2009). The study yielded a number of results, including the fact that compatibility between the functional aspects of work life and the employee's personal life is important, as is the presence of creativity and innovation.

Finally, two studies examined existing programs at two universities (one in Yemen, one in Cairo) to assess their educational techniques and quality standards. Al-Matari (2008) examined the production and use of educational techniques in Yemen by applying quality standards to analyze difficulties and problems. The study concluded that university education in Yemen does not keep up with the established quality standards. The study noted the importance of linking implemented programs with the needs of the labor market. The author recommended establishing programs to motivate employees to apply quality standards, providing office and technical equipment, implementing training programs, and conducting research, especially in terms of fulfilling the development objectives of Yemen and enabling employees to solve problems.

Ahmed and Hussein (2009) used questionnaires and personal interviews to survey two sample populations. The academic sample included college council members (62) and fourth-year students (804) from five faculties, while the labor market sample was selected to include heads of the student welfare offices in three universities, the directors of physical education, and the youth and sports sector in three governorates, for a total of 104. The most important results the researchers found included inadequate organizational culture; lack of the administrative, academic, and financial conditions necessary to apply total quality concepts; and a lack of quality educational services. A link between the needs of the labor market and the needs of graduates in terms of both quantity and quality was clearly lacking.

From this brief survey of the literature, we may conclude that compatibility between the outputs of universities and the needs of the Saudi labor market (so that it may benefit from global experience) requires the development of a strategic plan for cooperation between higher education institutions and the labor market. The latter is represented by the Ministry of Civil Service, Chambers of Commerce, and companies and factories in the private sector. Academic programs should be designed to yield the skills and knowledge needed to support these institutions. The current study ventures a step beyond the previous studies outlined here in that it uses a descriptive analytical approach and aims to demonstrate that the labor market needs outputs from a competitive $\mathrm{PhD}$ leadership program. It further proposes a doctoral program in the light of trends to date. 


\section{Study problem, objectives, and importance}

Suggest the Competitive Leadership Program, as one of the educational management paths in the Department of Educational Management and Planning in Princess Nourah bint Abdulrahman University, seeks to prepare qualified human resources with the competencies to help organizations achieve a competitive advantage. For this study, the researcher designed a standardized interview to identify the need in the Saudi market for an educational management program.

The problem of the study is encapsulated in one key question:

What the need for PhDs in the Saudi labor market?

A number of sub-questions emerge from the main question:

1. What are the locations of doctoral programs in educational management in Saudi universities?

2. What would be the competitive advantage of the $\mathrm{PhD}$ program in Educational Administration?

3. Are there any statistically significant differences among the answers of study participants owing to the variables of employer, years of experience, and the method of employment?

4. What should be included in a PhD program in educational administration?

To answer the research questions, the objectives of the study included the following:

1. To assess existing competitive $\mathrm{PhD}$ programs in leadership with an educational management focus in Saudi universities.

2. Determine the competitive advantage of $\mathrm{PhD}$ programs that have an educational management competitive leadership focus.

3. Identify statistical differences in the answers of the study population that relate to the employer variable, years of experience, and the method used in recruitment.

4. Determine which courses should be included in a PhD program with an educational management competitive leadership focus.

This study is important because it explores the efforts of universities to achieve a competitive advantage with their programs in relation to the objectives of society needs. As such, it has the potential to benefit university employees as they attempt to achieve the objectives to respond to the needs of society, as well as researchers in education who are seeking to improve those who control quality within university colleges and departments. The study may also help to improve evaluation results in universities at both the institutional and the program levels, and it may assist in linking the needs of Saudi society and development plans with the objectives of universities. It can help, as well, to ensure the financial welfare of the various graduate programs throughout the country.

\section{Research community and study population}

The current research community consists of education workers who would benefit from the proposed program in Saudi Arabia. The study sample included a random sample of workers in education in the Kingdom of Saudi Arabia age from more than 30 men and males.

Table 1 Description of sample population

\begin{tabular}{|l|l|l|}
\hline Variable & Category & Percentage \\
\hline Employer & $\begin{array}{l}\text { Public education: Director, Office of } \\
\text { General Education / leader }\end{array}$ & $24 \%$ \\
\cline { 2 - 3 } & $\begin{array}{l}\text { Public education: mentor of general } \\
\text { education }\end{array}$ & $24 \%$ \\
\cline { 2 - 3 } & University vice dean / faculty member & $52 \%$ \\
\hline \multirow{5}{*}{ Professional skills } & 1 - Less than 5 & $16 \%$ \\
\cline { 2 - 3 } & 5 -Less than 10 & $8 \%$ \\
\cline { 2 - 3 } & 10 - Less than 15 & $12 \%$ \\
\cline { 2 - 3 } & 15 and above & $64 \%$ \\
\hline \multirow{2}{*}{ Recruitment methods } & Website & $56 \%$ \\
\cline { 2 - 3 } & Employment exhibition & $24 \%$ \\
\cline { 2 - 3 } & Merit & $16 \%$ \\
\hline
\end{tabular}


Table 1 shows that the survey was administered about equally to public education employees (for a total of $48 \%$ ) and university employees (52\%). This distribution in the two main educational fields means that the knowledge gained in terms of useful academic programs should be wide-ranging and widely applicable. Notable as well is the large majority of the sample with over 15 years of job experience (64\%): their long experience in the field means they would also have a deep knowledge of what academic programs are needed in the educational labor market.

\section{Methodology}

The study begins with a diagnostic analysis of $\mathrm{PhD}$ programs in educational management in Saudi universities (Sikaran, 1998, p. 144) in order to assess the potential advantages of such PhD programs that are competitive. A standardized interview was designed for administering to a random sample of stakeholders (Al-Assaf, 1989), while library references, statistics, other documents, and circulars were used as necessary.

\section{Results}

\section{Validity of internal consistency}

The Pearson coefficient was used to calculate the internal consistency between the scores of each individual and the total score, as shown in Table 1.

\section{Table 2: Correlation coefficients between instrument vocabulary and overall score}

\begin{tabular}{|c|c|c|}
\hline Themes of the study & \begin{tabular}{|l|} 
Spearman \\
correlation \\
values
\end{tabular} & $\begin{array}{c}\text { Pearson } \\
\text { correlation } \\
\text { values }\end{array}$ \\
\hline $\begin{array}{l}\text { I support the opening of a competitive } \mathrm{PhD} \text { program in leadership as } \\
\text { one of the tracks of educational management. }\end{array}$ & $* * 0.92$ & $* * 0.95$ \\
\hline $\begin{array}{l}\text { The program will acquire graduates with knowledge and skills to } \\
\text { improve competitive leadership mechanisms. }\end{array}$ & $* * 0.87$ & $* * 0.91$ \\
\hline $\begin{array}{l}\text { The program enables competitive leadership in educational } \\
\text { institutions on a scientific basis. }\end{array}$ & $* * 0.77$ & $* * 0.83$ \\
\hline $\begin{array}{l}\text { The program will enable graduates to lead change in educational } \\
\text { institutions in the light of competitiveness. }\end{array}$ & $* * 0.90$ & $* * 0.95$ \\
\hline $\begin{array}{l}\text { The program will help to design competitive educational market } \\
\text { strategies. }\end{array}$ & $* * 0.95$ & $* * 0.98$ \\
\hline $\begin{array}{l}\text { The program will provide educational institutions with competitive } \\
\text { creative leadership skills. }\end{array}$ & $* * 0.72$ & $* * 0.80$ \\
\hline $\begin{array}{l}\text { There is a functional need for } \mathrm{PhD} \text { holders in the specialization of } \\
\text { educational management in the proposed program }\end{array}$ & $* * 0.91$ & $* * 0.91$ \\
\hline $\begin{array}{l}\text { The proposed program will efficiently implement the requirements of } \\
\text { the Kingdom's }\end{array}$ & $* * 0.92$ & $* * 0.92$ \\
\hline $\begin{array}{l}\text { The proposed program will prepare graduates capable of } \\
\text { implementing the Kingdom's with high quality }\end{array}$ & $* 0.70$ & $* 0.64$ \\
\hline $\begin{array}{l}\text { The proposed program will improve the performance of educational } \\
\text { institutions according to the requirements of society }\end{array}$ & $* 0.70$ & $* * 0.8$ \\
\hline
\end{tabular}


$*$ At the 0.05 level $* *$ At the 0.01 level

Table 2 shows that the correlation coefficients between the vocabularies used in the tool and the total score are high. They are positive, functioning at the 0.01 level for the majority of the study axes, which is a strong indicator of the validity of the tool's construction and composition.

\section{Stability}

The standardized interview was administered to a random sample to calculate the stability, where stability represents the degree of consistency when the measurement is repeated several times (Isaac, 1995). The alpha-CRB consistency of the random sample consisted of 12 responses with an alpha-CRB consistency of 0.80. This result enabled the application of the study tool because it is acceptable in the humanities (AlTariri, 1997, p. 185). The interviews were in the form of a written questionnaire that was distributed electronically and the results included in the tables.

\section{Analysis and Discussion}

The study data were analyzed using a number of appropriate statistical methods. SPSS was employed for applying appropriate statistical analysis, such as arithmetic mean, standard deviation, percentage (ANOVA), and Pearson correlation coefficient.

To answer the first research question concerning the state of doctoral programs in educational management in Saudi universities, the researcher explored existing doctoral programs in departments of management and educational planning in Saudi universities, as shown in Table3.

Table 3 Saudi universities providing doctoral programs in educational administration

\begin{tabular}{|l|l|}
\hline Program & University \\
\hline Educational administration & $\begin{array}{l}\text { College of Education, King Saud University, } \\
\text { Riyadh }\end{array}$ \\
\hline Educational management and planning & College of Education, Umm Al - Qura University \\
\hline
\end{tabular}

Table 3 demonstrates that existing $\mathrm{PhD}$ programs are generally concentrated in educational management so that there is considerable overlap. It also shows that specialization is lacking in the $\mathrm{PhD}$ programs identified. Thus, a program in educational management that focuses on competitive leadership skills would be distinctive, as it would offer new knowledge and skills that are needed by the educational labor market in Saudi Arabia.

The second research question asks about the likely competitive advantage of a $\mathrm{PhD}$ program in educational management.

To answer this question, the researcher applied percentages, means, and the standard deviation test to the results of the survey questions, as shown in Table 4. 
Table 4: Competitive advantage pf the PhD program in educational management

*Note: $\mathrm{SD}=$ strongly disagree; $\mathrm{D}=$ disagree; $\mathrm{N}=$ neutral; $\mathrm{A}=$ agree; $\mathrm{SA}=$ strongly agree.

\begin{tabular}{|c|c|c|c|c|c|c|c|}
\hline & \multicolumn{5}{|c|}{$\begin{array}{l}\text { Responses in percentage of } \\
\text { respondents }\end{array}$} & \multirow[t]{2}{*}{ Mean } & \multirow[t]{2}{*}{$\begin{array}{l}\text { Standard } \\
\text { deviation }\end{array}$} \\
\hline & SD* & D & $\mathbf{N}$ & $\mathbf{A}$ & SA & & \\
\hline $\begin{array}{l}\text { I support the opening of the PhD } \\
\text { program of competitive leadership } \\
\text { as one of the tracks of educational } \\
\text { management. }\end{array}$ & 8 & 8 & 8 & 20 & 56 & 1.9 & 1.3 \\
\hline $\begin{array}{l}\text { The program will acquire } \\
\text { graduates with knowledge and } \\
\text { skills to improve competitive } \\
\text { leadership mechanisms. }\end{array}$ & 4 & 16 & 4 & 24 & 52 & 1.96 & 1.3 \\
\hline $\begin{array}{l}\text { The program will enable } \\
\text { competitive leadership in } \\
\text { educational institutions on a } \\
\text { scientific basis. }\end{array}$ & 4 & 16 & 0 & 24 & 56 & 1.9 & 1.3 \\
\hline $\begin{array}{l}\text { The program will enable graduates } \\
\text { to lead change in educational } \\
\text { institutions to enhance } \\
\text { competitiveness. }\end{array}$ & 0 & 20 & 4 & 24 & 52 & 1.9 & 1.2 \\
\hline $\begin{array}{l}\text { The program will provide } \\
\text { educational institutions with } \\
\text { competitive creative leadership } \\
\text { skills. }\end{array}$ & 4 & 16 & 4 & 28 & 48 & 2 & 1.3 \\
\hline $\begin{array}{l}\text { The proposed program will } \\
\text { efficiently implement the } \\
\text { requirements of the Kingdom's }\end{array}$ & 4 & 16 & 4 & 24 & 52 & 1.96 & 1.3 \\
\hline $\begin{array}{l}\text { The proposed program will } \\
\text { prepare graduates capable of } \\
\text { implementing the Kingdom's with } \\
\text { high quality. }\end{array}$ & 16 & 8 & 8 & 24 & 44 & 2.3 & 1.5 \\
\hline $\begin{array}{l}\text { The proposed program will } \\
\text { improve the performance of } \\
\text { educational institutions according } \\
\text { to the requirements of the } \\
\text { Kingdom's. }\end{array}$ & 12 & 12 & 8 & 16 & 52 & 2.2 & 1.5 \\
\hline $\begin{array}{l}\text { The program will help to design } \\
\text { competitive educational market } \\
\text { strategies. }\end{array}$ & 4 & 16 & 4 & 28 & 48 & 2 & 1.3 \\
\hline $\begin{array}{l}\text { There is a functional need for } \mathrm{PhD} \\
\text { holders whose specialization is } \\
\text { educational management in the } \\
\text { proposed program. }\end{array}$ & 4 & 8 & 8 & 28 & 52 & 1.8 & 1.1 \\
\hline
\end{tabular}


Items to note in Table 4 include the standard deviation, which is between 1.1 and 1.5 , indicating the dispersion of the study sample. Two items in particular received strong support from a clear majority $(56 \%)$ : the proposal to open a doctoral level competitive leadership program and the idea that the program would attract graduates with the knowledge and skills to improve competitive leadership mechanisms. This level of support seems to confirm that there is a need to acquire knowledge and skills to improve the performance of competitive leadership in the educational environment.

Participants also widely agreed (52\%) that the program would fulfill the requirements, in which a strong goal is to improve the performance of education institutions. These results also indicate that participants perceive the need for such a program.

The third research question relates to possible statistically significant differences in the answers gleaned from the survey among the variables for employer, years of experience, and recruitment method used. To answer this question, the researcher used the variance test, as shown in Table 5.

Table 5 Test for possible discrepancies in answers as attributable to variables

\begin{tabular}{|c|c|c|c|c|c|c|c|}
\hline \multicolumn{2}{|c|}{ Variables } & Source & $\begin{array}{l}\text { Significance } \\
\text { level }\end{array}$ & $\begin{array}{l}\text { Value } \\
\text { (F) }\end{array}$ & $\begin{array}{l}\text { Average } \\
\text { squares } \\
\text { value }\end{array}$ & $\begin{array}{l}\text { Degree } \\
\text { of } \\
\text { freedom }\end{array}$ & $\begin{array}{l}\text { Total } \\
\text { squares }\end{array}$ \\
\hline \multirow{3}{*}{ 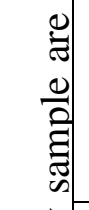 } & \multirow{3}{*}{ 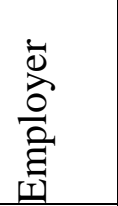 } & Between groups & \multirow[t]{3}{*}{0.83} & \multirow[t]{3}{*}{0.6} & 0.52 & 12 & 6.2 \\
\hline & & Within groups & & & \multirow[t]{2}{*}{0.90} & 12 & 10.9 \\
\hline & & Total & & & & 24 & 17.04 \\
\hline \multirow{3}{*}{ 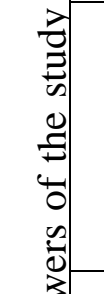 } & \multirow{3}{*}{ 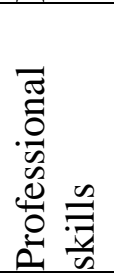 } & Between groups & \multirow[t]{3}{*}{0.5} & \multirow[t]{3}{*}{0.9} & 1.3 & 12 & 15.7 \\
\hline & & Within groups & & & \multirow[t]{2}{*}{1.4} & 12 & 16.9 \\
\hline & & Total & & & & 24 & 21.6 \\
\hline \multirow{3}{*}{ 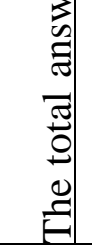 } & \multirow{3}{*}{ 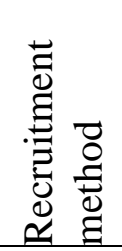 } & Between groups & \multirow[t]{3}{*}{0.4} & \multirow[t]{3}{*}{1.1} & 1.2 & 12 & 14.6 \\
\hline & & Within groups & & & \multirow[t]{2}{*}{1.1} & 12 & 13.3 \\
\hline & & Total & & & & 24 & 27.8 \\
\hline
\end{tabular}

Table 5 demonstrates that no statistically significant differences were found between the total answers of the study sample that could be attributed to any of the three variables: employer, years of experience, or recruitment method.

To answer the final research question concerning what a $\mathrm{PhD}$ program in educational administration with an emphasis on competitive leadership should look like, the researcher examined various $\mathrm{PhD}$ programs in a number of universities. Previous studies, as noted in the literature review, were also taken into account. 
Table 6: Study plan for a PhD program in educational leadership

6a.First semester

\begin{tabular}{|c|c|c|c|c|c|}
\hline \multirow{2}{*}{$\begin{array}{l}\text { Number } \\
\text { of credit } \\
\text { hours } \\
\text { required }\end{array}$} & \multicolumn{3}{|c|}{ Number of contact hours } & \multirow{2}{*}{$\begin{array}{l}\text { Course } \\
\text { type }\end{array}$} & \multirow[t]{2}{*}{ Course name } \\
\hline & Training & Practical & $\begin{array}{l}\text { Practical } \\
\text { theory }\end{array}$ & & \\
\hline 3 & - & & 3 & $\begin{array}{l}\text { Core } \\
\text { course }\end{array}$ & $\begin{array}{l}\text { Organizational Theory and Change in } \\
\text { Educational Institutions }\end{array}$ \\
\hline 3 & - & & 3 & $\begin{array}{l}\text { Core } \\
\text { course }\end{array}$ & The Economics of Education \\
\hline 3 & - & - & 3 & \begin{tabular}{|l} 
Core \\
course
\end{tabular} & $\begin{array}{l}\text { Leadership for Change in Educational } \\
\text { Institutions }\end{array}$ \\
\hline 3 & - & - & 3 & $\begin{array}{l}\text { Core } \\
\text { course }\end{array}$ & Elective \\
\hline
\end{tabular}

\section{6b. Second semester}

\begin{tabular}{|c|c|c|c|c|c|}
\hline \multirow{2}{*}{$\begin{array}{lr}\text { Number } & \text { of } \\
\text { credit } & \text { hours } \\
\text { required } & \end{array}$} & \multicolumn{3}{|c|}{ Number of contact hours } & \multirow{2}{*}{$\begin{array}{l}\text { Course } \\
\text { Type }\end{array}$} & \multirow{2}{*}{ Course Name } \\
\hline & Training & Practical & $\begin{array}{l}\text { Practical } \\
\text { Theory }\end{array}$ & & \\
\hline 3 & - & - & 3 & $\begin{array}{l}\text { Core } \\
\text { course }\end{array}$ & $\begin{array}{l}\text { Creative Leadership - Assessment, } \\
\text { Challenge and Support in Educational } \\
\text { Institutions }\end{array}$ \\
\hline 3 & - & - & 3 & $\begin{array}{l}\text { Core } \\
\text { course }\end{array}$ & $\begin{array}{l}\text { Making Meaning and the Collegiate } \\
\text { Experience in Educational Institutions }\end{array}$ \\
\hline 3 & - & - & 3 & $\begin{array}{l}\text { Core } \\
\text { course }\end{array}$ & $\begin{array}{l}\text { Entrepreneurship in } \\
\text { Institutions }\end{array}$ \\
\hline \multicolumn{3}{|c|}{9 hours +2 hours Seminar } & \multicolumn{3}{|l|}{ Total } \\
\hline
\end{tabular}

6c. Third semester: Project / Theory focus

\begin{tabular}{|c|c|c|c|c|c|}
\hline \multirow{2}{*}{$\begin{array}{l}\text { Number of credit } \\
\text { hours required }\end{array}$} & \multicolumn{3}{|c|}{ Number of contact hours } & \multirow{2}{*}{$\begin{array}{l}\text { Course } \\
\text { type }\end{array}$} & \multirow[t]{2}{*}{ Course name } \\
\hline & Training & Practical & $\begin{array}{l}\text { Practical } \\
\text { Theory }\end{array}$ & & \\
\hline 3 & - & - & 3 & Elective & Elective \\
\hline 3 & - & - & 3 & $\begin{array}{l}\text { Core } \\
\text { course }\end{array}$ & $\begin{array}{l}\text { Structure of Market Competition in } \\
\text { Educational Institutions }\end{array}$ \\
\hline 3 & - & - & 3 & $\begin{array}{l}\text { Core } \\
\text { course }\end{array}$ & $\begin{array}{l}\text { Models of Participatory Leadership } \\
\text { in Educational Institutions }\end{array}$ \\
\hline \multicolumn{3}{|c|}{9 Hours +2 hours Seminar } & \multicolumn{3}{|l|}{ Total } \\
\hline
\end{tabular}


6e. Elective Courses: Elective specialization requirement **

\begin{tabular}{|l|l|l|l|l|l|}
\hline $\begin{array}{l}\text { Number of } \\
\text { credit hours } \\
\text { required }\end{array}$ & Training & Practical & $\begin{array}{l}\text { Practical } \\
\text { Theory }\end{array}$ & Course & Course Name \\
\hline 3 & - & - & 3 & Elective & $\begin{array}{l}\text { Special Topics in } \\
\text { Leadership Studies in } \\
\text { Educational institutions }\end{array}$ \\
\hline 3 & - & - & 3 & Elective & $\begin{array}{l}\text { Internship in Educational } \\
\text { institutions }\end{array}$ \\
\hline 3 & - & - & 3 & Elective & $\begin{array}{l}\text { Branding and Marketing } \\
\text { of Higher Education }\end{array}$ \\
\hline 12 hours & & & Total & \\
\hline
\end{tabular}

\section{Limitations and Conclusions}

This study has geographic limitations, as it is limited to Saudi Arabia. It is also limited time-wise, as it was done during the 2018-2019 academic year. Thus, it may not have broad generalizability to other countries or to all times.

This study demonstrates the need in the labor market for programs offering a leadership emphasis in graduate educational management degrees that will enhance organizational competitiveness. This is especially true now that all graduate programs in public universities have shifted from free to fee-paying programs, which requires educational leaders to possess knowledge and skills that enable them to work in the educational market with a competitive advantage. Also, I recommend opening similar programs in Saudi universities in different regions to qualify students with the knowledge and skills that enable them to compete excellence in their performance in the labor market, and design similar programs focused on improving competitive performance that is consistent with the objectives of the Kingdom's needs. The results will benefit all international universities when designing doctoral programs in educational leadership it can develop a program that matches the needs of the global marketplace, which requires universities to provide students with the knowledge and skills to enable them to achieve competitive advantage with their performance. I therefore recommend that there be a global orientation in the design of doctoral programs that focus on providing the student with the knowledge and skills that enable him to work in a competitive market.

\section{References}

[1.] Abou El Wafa, G. (1990). Designing a management strategy for Egyptian universities using a systems approach and management methods with objectives, Unpublished PhD Thesis, Faculty of Education, Banha Branch, Zagazig University, Egypt.

[2.] Ahmed, A. \& Hussein, M. (2009). Quality assurance of higher education institutions in the light of the standards of international accreditation bodies. Cairo, Egypt: World of Books.

[3.] Al-Araini, Sara (2007). The impact of globalization on university education in the Arab world. Paper presented at the 7th International Conference on Educational Technology, Nicosia, Cyprus.

[4.] Ali, O. (2016). The foundation's mission and its role in achieving competitive advantage in sports institutions. (Unpublished master's thesis). Mohammed Boudiaf University-Messila, Algeria.

[5.] Al-Marei, M. (2011). The technical colleges in Saudi Arabia between objectives and functions: An analytical study. Journal of the Future of Arab Education, Vol.18.

[6.] Al-Matari, H. (2008). The reality of university education techniques and quality standards in Yemen. Journal of Studies in Curricula and Teaching Methods, 1(131), 160- 184.

[7.] Al-Otaibi, B. (2009). Methods of dealing with the lesser demanding scientific disciplines in higher education institutions in Saudi Arabia. Proceedings from Conference on Informatics and Arab 
Development Issues - Insights and Strategies. Sinai, Egypt: Arab Center for Education and Development.

[8.] Assaf, Saleh (1989). Introduction to research in the behavioral sciences. Riyadh, Alebkan publisher, Saudi Arabia.

[9.] Ayoub, N. (2008). The career trends of Saudi female students in the light of the determinants of employment in the private sector: An empirical study of the university studies center for girls and private sector managers, (unpublished doctoral dissertation), King Saud University, Riyadh, Saudi Arabia.

[10.] Bennett, John B., (1992). Management of the Academic Department Cases and Comments. Arab Renaissance House publisher, Cairo, Egypt.

[11.] Borg, W., \& Gall, Meredith, (1983), Educational Research, London, Longman, UK.

[12.] Gaber, Abdulhamed, Abdel Jawed, Salah (1992). The Arab renaissance publisher. Cairo, Egypt.

[13.] Hilal, N., \& Nasr, A. (2012). The internationalization of Egyptian higher education in the light of the challenges of globalization: A future vision. Journal of the Future of Arab Education, 77(April), 183- 316.

[14.] Isaac, S., \& Michael, W. (1995). Handbook in research and evaluation: For education and the behavioral sciences. San Diego, CA: EDITS.

[15.] Knight, P. \& Trawler, P., (2007), the art of leadership of the presidency of the university, translation: Khalid Al-Amri, Dar Al-Farouk for Publishing and Distribution, Cairo, Egypt.

[16.] Metwally, F. M., (2006). Evaluation of Egyptian private universities in the light of their objectives and some societal variables. (Unpublished doctoral dissertation) Mansoura University, Mansoura, Egypt.

[17.] Sayed Mostafa, A. (2000). Human resource management: A 21st century perspective. Cairo, Egypt: Dar Al Kutub.

[18.] Selmi, A. (2017). Future universities in the age of excellence and internationalism. Cairo, Egypt: Darsma Publishing.

[19.] Semlali, A. (2003). "TQM is an entrance to develop competitive advantage of the economic institution"Paper presented at First National Forum on the Algerian Economic Establishment and Challenges of the New Economic Climate, 22/23 April. University of Ouargla, Algeria.

[20.] Sencila, V., \& Skipariene, I. (2007). Application of ISO 9000 Series quality management standards at a higher education institution: A case of Lithuanian Maritime College. The Quality of Higher Education, 4, 53-73.

[21.] Shehata, S. (2009). Professional compatibility and its relationship to the perceived quality of life of working women. Journal of the Faculty of vol.1 Journal of the Faculty of Arts, Monofiya University, Cairo.

[22.] Sikaran, U. (1998). Research methods in management (I. Basyouni \& A. Al-Azzaz, Trans.). Riyadh, Saudi Arabia: King Saud University.

[23.] Strange, Z., \& Abdel-Moneim, M. (2008). Obstacles to the application of total quality standards in the educational colleges at King Faisal University and proposals for overcoming them. Journal of Psychological and Educational Research, Vol. 23, pp49-79.

[24.] Tariri, A. R. (1997). Psychological and educational measurement: Theories, foundations, and applications. Riyadh, Saudi Arabia: Al-Rushd Library.

[25.] Wolotkiewicz, R. (1986). College administrator's handbook. Boston, MA: Allyn and Bacon. 